\title{
Anna Ćwiąkala-Małys
}

Uniwersytet Wrocławski

e-mail: anna.cwiakala-malys@uwr.edu.pl

\section{Iwona Piotrowska}

Izba Administracji Skarbowej we Wrocławiu

e-mail: iwonapiotrowska@op.pl

\section{OBNIŻENIE LIMITU PLATNOŚCI GOTÓWKOWYCH JAKO ELEMENT EFEKTYWNEGO OGRANICZANIA SZAREJ STREFY W POLSCE}

\section{THE DROP OF CASH PAYMENT AS A PART OF AN EFFECTIVE GREY AREA REDUCTION IN POLAND}

DOI: $10.15611 /$ pn.2017.480.03

Streszczenie: Istnienie szarej strefy jest uwarunkowane swobodnym i niekontrolowanym przepływem gotówkowym. Wprowadzone zmiany w ustawie SDG dotyczące obniżenia limitu płatności gotówkowych wpływa na większość przedsiębiorców. Dotychczasowa liberalna polityka państwa w tym zakresie stwarzała możliwości swobodnego regulowania zobowiązań gospodarczych w formie płatności gotówkowej. Sprzyjało to możliwości dokonywania nadużyć i oszustw podatkowych. Zmiana stanowiska ustawodawcy, tj. ograniczenie limitu płatności gotówkowych, jest ukierunkowana na monitorowanie transakcji w formie bezgotówkowej. Odstępstwo od tej formy płatności może skutkować obowiązkiem skorygowania kosztów uzyskania przychodów, zwiększeniem podstawy opodatkowania i w rezultacie koniecznością zapłaty do budżetu wyższego podatku. Celem artykułu jest przedstawienie skutków podatkowych ograniczenia limitu płatności gotówkowych w obrocie gospodarczym, w kontekście możliwości zwiększenia wpływów do budżetu na skutek ograniczenia szarej strefy.

Słowa kluczowe: obrót gotówkowy, płatność gotówkowa i bezgotówkowa, koszty uzyskania przychodów, szara strefa.

Summary: The existence of grey area is conditioned by free and uncontrolled cash turnover. All the changes that were introduced in the act on freedom of business activity to reduce the limit of cash payments in a significant way will influence most entrepreneurs. Previous liberal state policy in this field created possibilities for free regulations of commitments on introducing economic transactions in a form of cash payments. The change of legislator's attitude i.e. the reduction of cash payment limit is oriented to monitor a transaction in a cashless form. Deviation from this form of payment may have an effect in an obligation to correct tax de- 
ductible expenses, increase the taxation base and as a result it will be inevitable to pay higher tax to the state budget.

Keywords: cash turnover, cash and cashless payment, tax deductible expenses, grey area.

\section{Wstęp}

Doświadczenia organów kontrolnych i podatkowych europejskich, w tym polskich, wskazują, że elementem sprzyjającym istnieniu szarej strefy może być swobodny przepływ gotówki związany z zawieranymi transakcjami gospodarczymi. Regulowanie zobowiązań gospodarczych pomiędzy kontrahentami nie zawsze odzwierciedla rzeczywisty przebieg transakcji.

Celem artykułu jest przedstawienie opinii dotyczących wprowadzenia ograniczenia limitu płatności gotówkowych w obrocie gospodarczym, a także wskazanie różnych aspektów wpływu obniżenia limitu płatności gotówkowej na sferę prowadzenia działalności gospodarczej oraz możliwości oddziaływania tej zmiany na zwiększenie wpływów do budżetu państwa na skutek ograniczenia szarej strefy.

W II półroczu 2015 r. Najwyższa Izba Kontroli przeprowadziła kontrolę Ministerstwa Finansów i jednostek mu podległych w zakresie skuteczności podejmowanych działań mających na celu przeciwdziałanie wprowadzaniu do obrotu gospodarczego faktur dokumentujących czynności fikcyjne. Kontrolą objęto działania podejmowane w 2014 r. i w I półroczu 2015 r. W ocenie NIK „działania organów skarbowych, aczkolwiek rzetelne i trafne, w wykrywaniu oszustw były nieskuteczne i spóźnione, gdyż nie ustalały faktycznych organizatorów oszustw podatkowych i nie wyegzekwowały wymierzonych podatków" [NIK o przeciwdziałaniu... 2016]. Według NIK mankamentem działań podejmowanych przez uprawnione organy skarbowe były trudności związane z ustaleniem sprawców oszustw podatkowych, szczególnie w zakresie zwalczaniu grup przestępczych wykorzystujących mechanizmy podatkowe do wyłudzania podatku VAT, i odzyskanie uszczuplonych kwot podatku VAT [Najwyższa Izba Kontroli, Przeciwdziałanie..., s. 13]. W raporcie podsumowującym wyniki przeprowadzonej kontroli wskazano, że ujawnienie fikcyjnych faktur przyczyniło się do zwiększenia zaległości w podatku od towarów i usług z tytułu wydanych decyzji (w trybie art. 108 ustawy o VAT) na koniec 2013 r. z wysokości 5,1 mld zł do stanu na dzień 30 czerwca 2015 r. do 14.100,5 mln zł [Najwyższa Izba Kontroli, Przeciwdziałanie..., s. 37], czyli w ciągu 1,5 roku zaległości wzrosły prawie trzykrotnie. Szanse na odzyskanie wymierzonych należności w podatku VAT z fikcyjnych faktur są niewielkie i szacowane na poziomie zaledwie 1,3\% wymierzonych kwot podatku wynikających z ww. decyzji. Do niskiej skuteczności egzekucji przyczynił się w głównej mierze fakt, iż zidentyfikowane podmioty uczestniczące w procederze wyłudzenia podatku VAT są tylko „słupami” i nie mają jakiegokolwiek majątku [NIK o przeciwdziałaniu... 2016]. 
W ocenie NIK zastosowane dotychczas rozwiązania systemowe, takie jak mechanizm odwrotnego obciążenia (reverse charge), instytucja odpowiedzialności solidarnej nabywcy, oraz rozwiązania organizacyjne okazały się niewystarczające dla poprawy skuteczności zwalczania oszustw popełnianych z wykorzystaniem faktur nieodzwierciedlających rzeczywistych transakcji gospodarczych oraz ograniczenia zagrożeń dla gromadzenia dochodów budżetu państwa [NIK o przeciwdziałaniu... 2016].

W raporcie NIK wskazano konieczność wdrożenia kolejnych rozwiązań zmierzających do zmniejszenia skali negatywnych zjawisk w zakresie wyłudzeń podatku VAT, m.in. takich jak [Najwyższa Izba Kontroli, Przeciwdziałanie..., s. 13-14]: centralny rejestr faktur, publiczny rejestr rachunków bankowych podatników, ograniczenie możliwości rozliczeń kwartalnych w VAT, powszechna standaryzacja ewidencji danych (dotyczących dokumentów, księgowań, płatności), dodanie kolejnych przesłanek warunkujących wykreślenie podatnika z rejestru podatników VAT, fakultatywna dzielona płatność (split payment) oraz ograniczenie płatności gotówkowych.

W opinii NIK dotychczasowe regulacje prawne oraz działania okazały się niewystarczające i nie pozwalają na skuteczne zabezpieczenie interesów Skarbu Państwa [Najwyższa Izba Kontroli, Przeciwdziatanie...].

\section{Obrót gotówkowy i bezgotówkowy}

J. Górka [2013, s. 14] twierdzi, że sprawny, szybki i bezpieczny transfer płynności (pieniądza gotówkowego i bezgotówkowego) jest warunkiem sine qua non właściwego funkcjonowania rynków realnych i finansowych. Dlatego jego zdaniem system płatniczy odgrywa zasadniczą rolę w każdej gospodarce.

W Polsce obrót bezgotówkowy, jako jeden z istotnych elementów systemu płatniczego, w coraz większym stopniu zaczyna powoli wypierać gotówkę - na korzyść innych instrumentów płatniczych, szczególnie kart płatniczych [Górka 2013, s. 66-67].

O płatności w formie gotówkowej mówimy, jeśli na którymkolwiek z etapów procesu świadczenie realizowane jest w postaci gotówki. Za płatności gotówkowe uznaje się płatności, w których banknoty i monety (tzw. medium pośredniczące) stosowane są na etapie zarówno inicjacji płatności, jak i rozrachunku (np. przekaz pocztowy), oraz takie płatności, w których etap inicjacji przeprowadzany jest z użyciem gotówki, ale rozrachunek odbywa się w formie bezgotówkowej (np. wpłata gotówkowa na rachunek bankowy) [Kisiel 2017, s. 7].

Przez płatności bezgotówkowe należy rozumieć proces, w którym na każdym etapie cyklu rozliczeniowego transfer środków pieniężnych odbywa się za pośrednictwem rachunków bankowych, rachunków płatniczych prowadzonych przez uprawnione do tego podmioty lub pieniądza elektronicznego. Oznacza to, że w żadnym z etapów procesu nie jest używana gotówka [Kisiel 2017, s. 7].

Obrót bezgotówkowy znacznie przyspiesza płatności pomiędzy uczestnikami rynku gospodarczego, obniża koszty funkcjonowania podmiotów gospodarczych, 
gdyż nie wymaga fizycznego kontaktu pomiędzy stronami transakcji gospodarczej celem jej finalizacji czy też korzystania z pośrednika finansowego. Zasadniczą różnicą między obrotem bezgotówkowym a gotówkowym jest to, że obciążenie rachunku płatnika i uznanie rachunku odbiorcy nie wymaga użycia medium pośredniczącego, czyli banknotów i monet [Górka 2013, s. 32]. Jedną z istotnych cech obrotu bezgotówkowego, oprócz bezpieczeństwa, jest jego transparentność, czyli jawność i identyfikowalność uczestników łańcucha przepływów pieniężnych, lecz nie koniecznie jawne poza samym systemem (np. elektroniczne zabezpieczenia, procedura logowania i autoryzacji transakcji, informacje objęte klauzulą „tajemnica bankowa"). Równie ważną cechą obrotu bezgotówkowego jest możliwość odtworzenia łańcucha przebiegu/transferu środków pieniężnych co do ich ilości, częstotliwości transferu oraz czasu ulokowania na rachunkach płatnika i odbiorcy. Dostępność do wyżej wymienionych informacji jest jednak ograniczona i dostępna wyłącznie podmiotom uprawnionym. Istnieją przepisy prawne regulujące procedury pozyskiwania tych informacji ustalone przez organy i instytucje odpowiedzialne za bezpieczeństwo krajowego systemu bankowego. Tylko uprawnione organy, w tym m.in. ścigania i kontroli podatkowo-skarbowej, mogą na mocy zapisów ustawowych pozyskać informacje $\mathrm{z}$ instytucji finansowych.

Badania przeprowadzone wśród polskich przedsiębiorców dotyczące płatności gotówką w 2011 r. wskazują, że stanowiły one 87\% liczby dokonanych transakcji. Ponadto im większa firma, tym udział płatności gotówkowych był niższy. W firmach akceptujących karty płatnicze procent płatności realizowanych gotówką wyniósł 71\% [Górka 2013, s. 66]. Powyższe wyniki nie oznaczają jednak, że:

- transakcje gotówkowe w większości zasilają szarą strefę,

- im mniejsza firma, tym większe prawdopodobieństwo wystąpienia transakcji w szarej strefie,

- wszystkie transakcje bezgotówkowe rzeczywiście odzwierciedlają faktyczne transakcje gospodarcze.

Zwolennicy ograniczania obrotu gotówkowego powołują się na wyniki badań zagranicznych, które wskazały, że gotówka jest często wykorzystywana jako pośrednik wymiany w szarej i czarnej strefie. Autorzy prac na temat zjawiska szarej strefy w polskiej gospodarce twierdzą, że jest skutkiem dużego udziału gotówki w obrocie gospodarczym. Ich zdaniem w Polsce można by ograniczać szarą strefę poprzez zwiększania roli obrotu elektronicznego. Na rysunkach 1-2 przedstawiono limity płatności gotówkowych obowiązujących w niektórych krajach europejskich i szacowaną wartość udziału szarej strefy w \% PKB (według stanu na koniec 2015 r.).

Wykresy na rys. 1 i 2 nie wskazują jednoznacznie, że wysokie limity płatności gotówkowych towarzyszą jednocześnie wysokiemu udziałowi szarej strefy w PKB.

Przedstawiciele Ministerstwa Rozwoju twierdzą, iż płatności gotówkowe, w przeciwieństwie do elektronicznych, nie pozostawiają śladu, umożliwiając ukrycie transakcji. W efekcie mogą prowadzić do powstawania szarej strefy, nawet w sytuacji, gdy jedna strona transakcji (najczęściej osoba dokonująca płatności gotówkowej) 
Limit płatności gotówkowych (w euro)

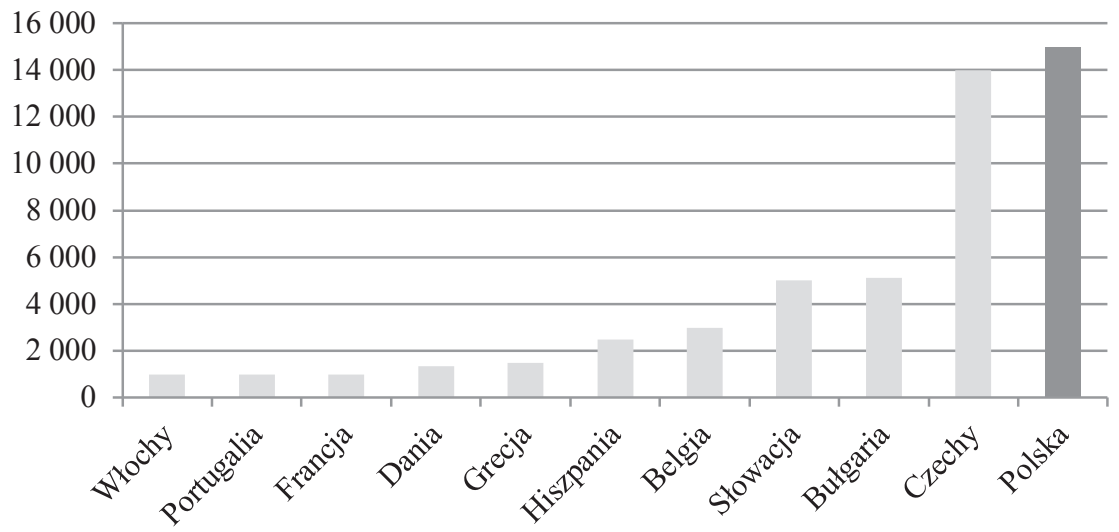

Rys. 1. Limity płatności gotówkowych obowiązujących w niektórych krajach europejskich (według stanu na koniec 2015 r.)

Źródło: opracowanie własne na podstawie danych ze strony http://dyskusja.biz/finanse/w-europie-trwa-wojna-wojna-z-gotowka-54251 (25.05.2017).

Szacunkowy udział szarej strefy w PKB (\%)

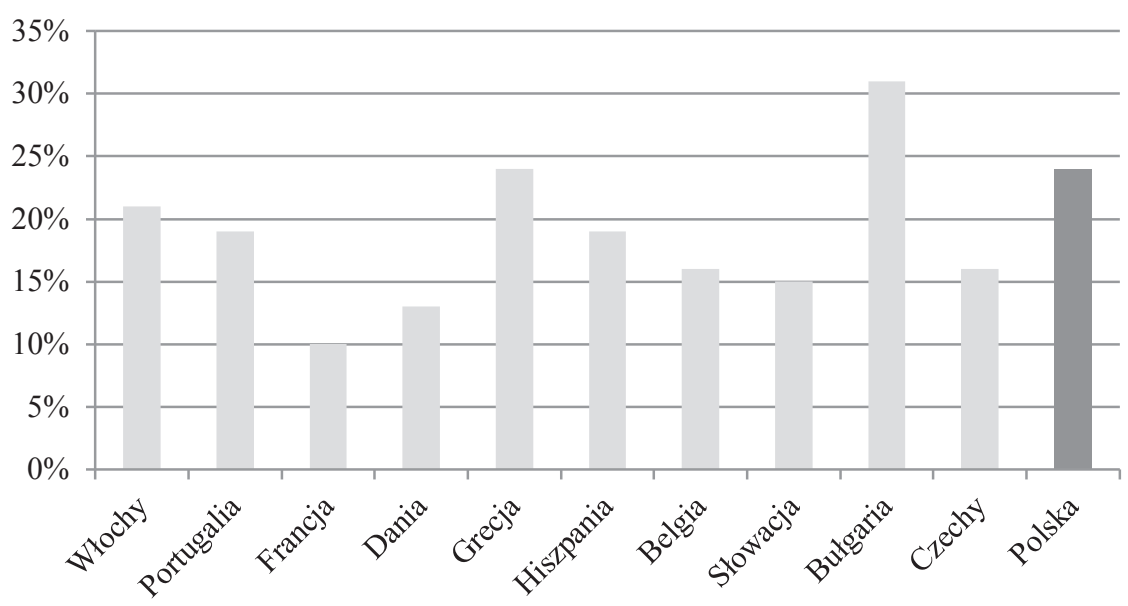

Rys. 2. Szacowana wartość udziału szarej strefy w \% PKB (według stanu na koniec 2015 r.).

Źródło: opracowanie własne na podstawie danych ze strony http://dyskusja.biz/finanse/w-europie-trwa-wojna-wojna-z-gotowka-54251 (25.05.2017).

nie jest tego świadoma (tzw. pasywna szara strefa). Tym samym wprowadzenie regulacji zmniejszającej rolę gotówki w gospodarce na rzecz płatności elektronicznych może przyczynić się do ograniczenia szarej strefy w gospodarce i w efekcie do 
poprawy sytuacji konkurencyjnej uczciwych podmiotów i zwiększenia dochodów sektora finansów publicznych [Odpowiedź na Interpelację...].

Również Ministerstwo Finansów powołuje się na efekty ekonomiczne ograniczenia płatności gotówkowych w Hiszpanii, gdzie obniżenie limitu do poziomu 2500 euro spowodowało spadek szacowanej wartości szarej strefy z 19,2\% do 18,6\% PKB, czyli o 0,6 p.p. Natomiast w Portugalii wskutek obniżenia limitu płatności gotówkowych nastąpił spadek szarej strefy z 19,6\% do 17,6\% PKB, czyli o 2 p.p. Resort Finansów oszacował, że w Polsce w wyniku wprowadzenia ograniczenia limitu płatności gotówkowej wpływy do budżetu będą o 2 mld zł wyższe [Sejm przeglosowat...].

\section{Limit transakcji gotówkowej po 1 stycznia 2017 r. i jego skutki}

Na początku 2016 r. zakończono pracę nad projektem nowelizacji ustawy z dnia 26 lipca 1991 r. o podatku dochodowym od osób fizycznych (tekst jednolity Dz.U. 2016, nr 0, poz. 2032; dalej ustawa o PIT) i Ustawy z dnia 15 lutego 1992 r. o podatku dochodowym od osób prawnych (tekst jednolity Dz.U. 2016, nr 0, poz. 1888; dalej ustawa o CIT) oraz Ustawy z dnia 2 lipca 2004 r. o swobodzie działalności gospodarczej (tekst jednolity Dz.U. 2016, nr 0, poz. 1829; dalej ustawa o SDG). W następstwie powyższego uchwalono ustawę z dnia 13 kwietnia 2016 r. o zmianie ustawy o podatku dochodowym od osób fizycznych, ustawy o podatku dochodowym od osób prawnych oraz ustawy o swobodzie działalności gospodarczej ${ }^{1}$. Wprowadzono przedmiotowe regulacje dotyczące obniżenia limitu transakcji gotówkowej, która określa skutki podatkowe po stronie kosztów uzyskania przychodów. Zmiany weszły w życie z dniem 01.01.2017 r.

Od 2017 r. znowelizowany przepis art. 22 ustawy o SDG otrzymał brzmienie: „dokonywanie lub przyjmowanie płatności związanych z wykonywaną działalnością gospodarczą następuje za pośrednictwem rachunku płatniczego przedsiębiorcy, w każdym przypadku gdy:

- stroną transakcji, z której wynika płatność, jest inny przedsiębiorca oraz

- jednorazowa wartość transakcji, bez względu na liczbę wynikających z niej płatności przekracza równowartość $15000 \mathrm{zl}$, przy czym transakcje w walutach obcych przelicza się na złote według kursu średniego walut obcych ogłaszanego przez Narodowy Bank Polski z ostatniego dnia roboczego poprzedzającego dzień dokonania transakcji”.

\footnotetext{
${ }^{1}$ Art. 1 i 2 Ustawy z dnia 13 kwietnia 2016 r. o zmianie ustawy o podatku dochodowym od osób fizycznych, ustawy o podatku dochodowym od osób prawnych oraz ustawy o swobodzie działalności gospodarczej nowelizuje przepisy Ustawy z dnia 26 lipca 1991 r. o podatku dochodowym od osób fizycznych (Dz. U. 2012 r., 361, z późn. zm.) oraz Ustawy z dnia 15 lutego 1992 r. o podatku dochodowym od osób prawnych (Dz. U. 2014 r. poz. 851 z późn. zm.); art. 3 ww. ustawy dotyczy zmian w ustawie o swobodzie działalności gospodarczej.
} 
W konsekwencji ww. nowelizacji zmianie uległ art. 22 ust. 1 ustawy o PIT, tj. nadano mu nowe brzmienie i dodano nowy art. 24e ust. 1-3, oraz odpowiednio art. 15 ust. 1 ustawy o CIT, w którym dodano art. 15d ust. 1-3. Obie zmiany dotyczą sposobu zaliczania do kosztów uzyskania przychodów kwoty płatności dokonanej z naruszeniem obowiązku określonego w art. 22 ustawy z dnia 2 lipca 2004 r. o swobodzie działalności gospodarczej przez m.in. podatników prowadzących pozarolniczą działalność gospodarczą. Na skutek naruszenia ww. przepisu podatnicy:

1) zmniejszają koszty uzyskania przychodów albo

2) zwiększają przychody - w przypadku braku możliwości zmniejszenia kosztów uzyskania przychodów - o kwotę płatności wynikającą z faktury (rachunku), umowy lub innego dokumentu w miesiącu, w którym została dokonana płatność.

Zasadniczo zmiany te polegają na wyłączeniu możliwości zaliczenia do kosztów uzyskania przychodów kosztu w tej części, w jakiej kwota płatności dotycząca transakcji określonej w ustawie o SDG, czyli równowartości co najmniej 15000 zł, została dokonana bez pośrednictwa rachunku płatniczego. W konsekwencji naruszenia ww. przepisu podatnik (nabywca) ma obowiązek zmniejszenia kosztów uzyskania przychodów (lub zwiększenia przychodów w przypadku braku możliwości zmniejszenia kosztów) ${ }^{2}$, czyli zwiększa podstawę opodatkowania podatkiem dochodowym i podatek należny dla budżetu.

W wyjaśnieniach zamieszczonych na stronie internetowej Ministerstwa Finansów [Nowe przepisy...] wskazano, że ,wprowadzane od 01.01.2017 r. przepisy podatkowe odwołują się do pojęcia »płatności«, wynikającej z transakcji (o której mowa w art. 22 ustawy o SDG), a zatem obejmują wyłącznie wskazany w nich sposób regulowania zobowiązania, tj. poprzez dokonywanie zapłaty. Przedmiotowe regulacje nie znajdą zastosowania do innych form regulowania (wygasania) zobowiązań, które ze swojej istoty nie mają charakteru płatności i nie są związane z rachunkiem płatniczym. W związku z tym formy uregulowania zobowiązań, takie jak m.in. kompensata (potrącenie) czy wymiana barterowa, nie są objęte omawianymi przepisami. Jakkolwiek dochodzi wówczas do uregulowania (wygaśnięcia) zobowiązania, to jednak strony umowy nie dokonują ,płatności”, które mogłyby być objęte zakresem tych regulacji. Jednocześnie w przypadku płatności, które odbywają się za pomocą instrumentów płatniczych, związanych z rachunkami płatniczymi, takimi jak m.in. karty płatnicze, jak również płatności dokonywanych poprzez systemy pośredniczące w płatnościach, takie jak PayPal, PayU itp., będzie spełniony wymóg dokonania ich za pośrednictwem rachunku płatniczego" [Nowe przepisy...] .

Negatywnie do części ww. zmian w ustawach o PIT i CIT odnieśli się przedstawiciele Związków Pracodawców Business Center Club (dalej ZP BCC) ${ }^{3}$ i Związku

\footnotetext{
${ }^{2} \mathrm{~W}$ przypadku transakcji odnoszącej się do kosztu zaliczonego uprzednio do kosztów uzyskania przychodów. W tym przypadku zmniejszenie kosztów uzyskania przychodów (zwiększenie przychodów) będzie dokonywane w miesiącu dokonania płatności z pominięciem rachunku płatniczego.

${ }^{3} \mathrm{https} / / /$ legislacja.rcl.gov.pl/docs//2/12281453/12334307/.../dokument207865.pdf.
} 
Przedsiębiorców i Pracodawców (dalej ZPiP) ${ }^{4}$. W szczególności krytykowano element znacznego obniżenia limitu płatności gotówkowej za wydatki zaliczone do kosztów uzyskania przychodów z równowartości 15000 euro do 15000 zł (czyli o 3/45) oraz wysokiej sankcji, tj. braku możliwości zaliczenia wydatku w kwocie nadwyżki ponad wyznaczony limit bezpośrednio do kosztów uzyskania przychodów. Powyższe regulacje oceniono jako ograniczenie swobody działalności gospodarczej. Według ZP BCC i ZPiP pierwotnym zamierzeniem autorów projektu było wyłącznie zmniejszenie szarej strefy i zwiększenie dochodów budżetu państwa.

\section{Dalsze zmiany dotyczące płatności bezgotówkowych}

Ustawodawca prowadzi prace nad kolejną zmianą związaną z kontrolą państwa nad płatnościami w obrocie gospodarczym polegającą na obowiązku banków i innych firm z branży finansowej przekazywania informacji o wszystkich transakcjach o wartości ponad $15000 \mathrm{zł}$ (według projektu nowej ustawy o przeciwdziałaniu praniu pieniędzy oraz finansowaniu terroryzmu [Banki będę informować...]; aktualnie ustawa z dnia 16 listopada 2000 r. o przeciwdziałaniu praniu pieniędzy oraz finansowaniu terroryzmu - t.j. Dz.U. 2016 poz. 299 z późn. zm.).

Ekspert Konfederacji Lewiatan (Anna Dużyńska-Pucha) [Konfederacja Lewiatan 2017] twierdzi, że cześć planowanych zmian przepisów wykracza poza obowiązującą w tym zakresie unijną dyrektywę. Dotyczy to obowiązku raportowania transakcji o wartości przekraczającej $15000 \mathrm{zl}$, podczas gdy dyrektywa wskazuje taki obowiązek dla transakcji o kwocie 10000 euro, czyli ok. 45000 zł. Dyrektywa umożliwia państwom członkowskim wprowadzenie przepisów nakazujących raportowanie transakcji poniżej określonego progu kwotowego, które ze względu na jakieś szczególne cechy mogą być uznane za podejrzane, a ze względu na specyfikę rynku danego państwa kryteria wskazane w dyrektywie ich nie obejmują.

Również niektórzy analitycy krytycznie oceniają dokonane zmiany w Europie powyższym zakresie. Twierdzą, że obniżanie limitów płatności gotówkowych jest prowadzone pod pretekstem walki z szarą strefą, terroryzmem i przestępcami. Wskazują, że najbardziej „drakońskie prawo” zwalczające obrót gotówkowy wprowadziła Francja. Od 01.09.2015 r. limit płatności gotówkowych został tam obniżony z 3000 euro do zaledwie 1000 euro [Kolany 2017b].

\section{Ocena skutków wprowadzanych zmian}

Wśród korzyści płynących dla budżetu państwa, wynikających z obniżania limitu transakcji gotówkowych oraz monitorowania niektórych płatności bezgotówkowych, należy wymienić:

${ }^{4} \mathrm{https} / / /$ legislacja.rcl.gov.pl/docs//2/12281453/12334307/.../dokument207864.pdf.

${ }^{5}$ Kurs średni Narodowego Banku Polskiego na pierwszy dzień roboczy w 2017 r., czyli na dzień 02.01.2017 r. wynosił 4,4157 zł (Tabela nr 001/A/NBP/2017 z dnia 2017-01-02); 4,4157 zł x 15000 euro $=66235,50 \mathrm{zl}$. 
- transparentność systemu rozliczeń pomiędzy podmiotami z punktu widzenia organów kontrolnych, w tym fiskalnych;

- utrzymywanie wyższych kwot środków pieniężnych na rachunkach rozliczeniowych - możliwość egzekucji na poczet zobowiązań publicznoprawnych; ułatwienie prowadzenia czynności weryfikacyjnych dotyczących transakcji mogących wskazywać na próby wyłudzenia podatku VAT;

- ułatwienie prowadzenia czynności weryfikacyjnych dotyczących transakcji mogących wskazywać na dokumentowanie fikcyjnych transakcji gospodarczych (przede wszystkim o charakterze kosztowym);

- szybsze i skuteczniejsze działania organów egzekucyjnych;

- trafniejsze identyfikowanie podmiotów „słupów”, na które zakładane są rachunki bankowe wyłącznie celem wyłudzenia zwrotu podatku VAT;

- ograniczenie szarej strefy;

- zwiększenie wpływów do budżetu państwa.

Natomiast z punktu widzenia przedsiębiorców przedmiotowe zmiany:

- wymuszą rzetelność w zakresie terminowości płatności za zobowiązania (na zasadzie wzajemności);

- zweryfikują informacje o potencjalnych nierzetelnych kontrahentach obecnych na rynku w zakresie terminowości i rzetelności wywiązywania się z zobowiązań wobec kontrahentów;

- zmniejszą ryzyko związane z kradzieżą gotówki;

- zmniejszą koszty związane z utrzymaniem gotówki w firmie;

- ograniczą ryzyko przyjęcia fałszywych banknotów.

Ponadto po stronie ewentualnych zagrożeń wymienić należy:

- ograniczenie swobody działalności gospodarczej przedsiębiorców wynikające m.in. z sankcji wskazanych w ustawach PIT i CIT dotyczących kosztów uzyskania przychodów;

- wzrost kosztów - konieczność opłacenia obsługi transakcji bezgotówkowych;

- zwiększenie skuteczności egzekwowania przez organy egzekucyjne zobowiązań publicznoprawnych z tytułu zawartych fikcyjnych transakcji lub mających na celu wyłudzenia podatku VAT;

- konieczność utrzymywania środków pieniężnych na rachunkach bankowych przeznaczonych do regulowania płatności - środki, które nie znajdują się w obrocie i „nie pracują";

- konieczność zaciągania kredytów obrotowych w instytucjach obsługujących rachunki do rozliczeń w przypadku chwilowego lub sezonowego braku płynności podmiotu;

- możliwe wydłużenie okresu oczekiwania na płatności od kontrahentów z tytułu zawartych i dokonanych transakcji gospodarczych, nawet tych o wartości niewiele przewyższających ustalony limit.

Jedną z głównych barier akceptacji przez przedsiębiorców przyjętych rozwiązań prawnych może być bariera psychologiczna wynikające z przekonania, iż zmiany są 
przejawem nadmiernej ingerencji państwa w swobodę i wolność prowadzenia działalności gospodarczej. Jednak nie wszystkie z powyżej opisanych zmian wskazują na ewentualny nadmierny fiskalizm państwa. Zmiany te wynikają przede wszystkim z konieczności dostosowania się do międzynarodowych standardów bezpieczeństwa ekonomicznego i politycznego, w tym zapobiegania finasowania terroryzmu i transferowaniu środków pieniężnych z szarej i czarnej strefy.

\section{Zakończenie}

Reasumując, należy podkreślić, iż wprowadzone zmiany z punktu widzenia budżetu państwa mają charakter pozytywny, gdyż mogą przyczynić się do efektywnego zwalczenia szarej strefy, szczególnie ujawniać przejawy działań mających znamiona oszustw podatkowych i wyłudzeń podatku VAT. Ponadto pomogą organom skarbowym skuteczniej egzekwować zobowiązania publicznoprawne oraz w konsekwencji zwiększyć wpływu do budżetu państwa.

\section{Literatura}

Banki będę informować o wszystkich transakcjach przekraczających 15 tys. zł, 2017, GazetaPodatnika. $\mathrm{pl}, \mathrm{nr}$ 75(2205).

Górka J., 2013, Efektywność instrumentów platniczych w Polsce, Wydawnictwo Naukowe Wydziału Zarządzania Uniwersytetu Warszawskiego, Warszawa.

http://www.gazetapodatnika.pl/artykuly/banki_beda_informowac_o_wszystkich_transakcjach_przekraczajacych_15_tys_zl-a_22167.htm (16.05.2017).

https://www.podatki.biz/artykuly/kodeks-pracy-beda-zmiany-w-formie-wyplaty-wynagrodzenia_ 14_34798.htm?idDzialu=14\&idArtykulu=34798 (16.05.2017).

Kisiel M., 2017, Niekartowe schematy płatności bezgotówkowych w Polsce, http://www.nbp.pl/systemplatniczy/obrot_bezgotowkowy/niekartowe-Polska.pdf (24.05.2017).

Kolany K., W Europie trwa wojna. Wojna z gotówka, http://dyskusja.biz/finanse/w-europie-trwa-wojna-wojna-z-gotowka-54251 (25.05.2017a).

Kolany K., Zwalczanie gotówki nie wyeliminuje szarej strefy, http://www.bankier.pl/wiadomosc/ Sejm-przeglosowal-obnizenie-limitu-transakcji-gotowkowych-do-15-tys-zl-3514148.html (24.05.2017b).

Konfederacja Lewiatan, 2017, Lewiatan: Raportowanie transakcji powyżej 15 tys. zt niezgodne z unijna dyrektywa, http://wzp.org.pl/lewiatan-raportowanie-transakcji-powyzej-15-tys-zl-niezgodne-zunijna-dyrektywa/ (24.05.2017).

Ministerstwo Finansów, Nowe przepisy dot. skutków podatkowych przy regulowaniu płatności w formie gotówkowej, http://www.finanse.mf.gov.pl/web/bip/ministerstwo-finansow/dla-mediow/informacje-prasowe/-/asset_publisher/6PxF/content/id/5807440 (13.10.2016).

Najwyższa Izba Kontroli, 2016, NIK o przeciwdziałaniu wyludzaniu VAT, 07.04.2016 r., https://www. nik.gov.pl/aktualnosci/nik-o-przeciwdzialaniu-wyludzaniu-vat.html (02.02.2017).

Najwyższa Izba Kontroli, Przeciwdziałanie wprowadzaniu do obrotu gospodarczego faktur dokumentujących czynności fikcyjne, Informacja o wynikach kontroli KBF.410.007.00.2015, https://www. nik.gov.pl/plik/id,10427,vp,12756.pdf (02.02.2017). 
Odpowiedź na Interpelację nr 11861 do ministra rozwoju w sprawie ograniczenia wypłat gotówkowych dla pracowników.

Sejm przegłosował obniżenie limitu transakcji gotówkowych do 15 tys. zt, http://www.bankier.pl/wiadomosc/Sejm-przeglosowal-obnizenie-limitu-transakcji-gotowkowych-do-15-tys-zl-3514148.html, 2016-04-13 (24.05.2017).

Ustawa z dnia 13 kwietnia 2016 r. o zmianie ustawy o podatku dochodowym od osób fizycznych, ustawy o podatku dochodowym od osób prawnych oraz ustawy o swobodzie działalności gospodarczej (Dz. U. 2016, nr 0, poz. 780).

Ustawa z dnia 15 lutego 1992 r. o podatku dochodowym od osób prawnych (tekst jednolity Dz.U. 2016, nr 0, poz. 1888).

Ustawa z dnia 2 lipca 2004 r. o swobodzie działalności gospodarczej (tekst jednolity Dz.U. 2016, nr 0, poz. 1829).

Ustawa z dnia 26 lipca 1991 r. o podatku dochodowym od osób fizycznych (tekst jednolity Dz. U. 2016, nr 0, poz. 2032).

Wieloletni Plan Finansowy Państwa na lata 2017-2020, Warszawa 2017, www.mf.gov.pl/documents/764034/5874533/20170428_WPFP_2017_2020.pdf(16.05.2017). 